\title{
GNAI3 wt Allele
}

National Cancer Institute

\section{Source}

National Cancer Institute. GNA13 wt Allele. NCI Thesaurus. Code C52645.

Human GNAI3 wild-type allele is located in the vicinity of $1 \mathrm{p} 13$ and is approximately $45 \mathrm{~kb}$ in length. This allele, which encodes guanine nucleotide-binding protein $\mathrm{G}(\mathrm{k})$ subunit alpha protein, is involved in the progression of 7-transmembrane domain receptor-dependent signaling pathways. 